\title{
A VALIDATED STABILITY INDICATING ION EXCHANGE CHROMATOGRAPHIC METHOD FOR THE QUANTIFICATION OF ALENDRONATE, PHOSPHITE AND PHOSPHATE IN ALENDRONATE SODIUM TABLETS AND ANALYSIS OF IN-VITRO DISSOLUTION SAMPLES
}

\author{
P. SUNIL REDDY *a, ${ }^{\text {, }}$ K. SUDHAKAR BABU ${ }^{b}$, NAVNEET KUMAR ${ }^{a}$, P. BALAKRISHNA ${ }^{a}$ \\ ${ }^{a}$ Dr. Reddy's Laboratories Ltd., IPDO, Bachupally, Hyderabad-500072, A.P, India. \\ ${ }^{b}$ Department of Chemistry, S. K. University, Anantapur -515055, A.P., India.
}

(Received: November 16, 2011 - Accepted: February 29, 2012)

\begin{abstract}
A stability-indicating LC method was developed on ion exchange chromatography equipped with refractive index detector for the quantification of phosphite, phosphate content and assay of alendronic acid in pharmaceutical dosage forms. The isocratic separation was achieved by using Allsep anion (150mm $\mathrm{x} 4.6 \mathrm{~mm}$ ) $7 \mu \mathrm{m}$ column with mobile phase containing a $5.3 \mathrm{mM}$ formic acid, $\mathrm{pH}$ adjusted to 3.5 with sodium hydroxide solution at a flow rate of $1.2 \mathrm{~mL} / \mathrm{min}$. Alendronate sodium was subjected to the stress conditions of oxidative, acid, base, hydrolytic, thermal and photolytic degradation. Alendronate sodium was found to degrade significantly in oxidative stress conditions only. The developed method was extensively validated as per ICH guidelines with respect to specificity, linearity, limit of detection and quantification, accuracy, precision and robustness. The developed LC method was successfully applied for analysis of in-vitro dissolution samples of marketed alendronate sodium tablets.
\end{abstract}

Keywords: Ion exchange chromatography, Refractive index detector, Phosphate, Phosphite, Alendronate sodium.

\section{INTRODUCTION}

Alendronate sodium is a bisphosphonate and act as a specific inhibitor of osteoclast-mediated bone resorption. Alendronate sodium is chemically described as (4-amino-1-hydroxybutylidine) bisphosphonic acid monosidum salt trihydrate (Figure 1) and used clinically for metastatic bone disease, hypercalcemia of malignancy, Paget's disease and osteoporosis ${ }^{1,2}$.

One of the major drawback for the analysis of phosphite, phosphate and alendronate is the lack of chromophore groups, making difficult the use of UV detector. Several approaches are reported for the quantification of alendronate sodium in pharmaceutical formulation and biological fluids, many of which relied on derivatization of alendronate, using pre-column ${ }^{3}$ and post-column techniques ${ }^{4}$. Direct HPLC analysis of alendronate using conductivity detection ${ }^{5}$, indirect UV detection ${ }^{6}$ and fluorescent detection ${ }^{7-9}$ has been reported. Ion chromatography-ion spray mass spectrometric alendronate characterization of alendronate was presented ${ }^{10}$. Few HPLC methods for the determination of alendronate were employed by derivatization with 9-fluorenylmethyl chloroformate (FMOC) ${ }^{11,12}$. Alendronate sodium tablets monograph has been reported in United State Pharmacopoeia (USP) ${ }^{13}$. HPLC methods reported in USP monograph for the quantification of alendronate in assay and dissolution samples are based on derivatization with FMOC, which is an expensive, difficult and time consuming process. Only one ion chromatography method with refractive index (RI) detection was reported for the quantification of alendronate sodium ${ }^{14}$. Reported method has two main disadvantages: One nitric acid was used as mobile phase which is toxic strong acid and corrosive in nature and could be harmful to the stainless steel parts of the chromatography system. Second, forced degradation study for alendronate sodium was not performed to prove the stability indicating ability of the method. According to current Good Manufacturing Practices (cGMP) and International Conference on Harmonization (ICH) guidance, all drugs must be tested with a stability indicating assay method before release and during shelf life. Phospahate and phosphite are possible degradation products of alendronate sodium. In best of our knowledge, no stability indicating HPLC-RI method is reported for the quantification of alendronate, phosphate and phosphite in alendronate sodium tablets. It was felt to develop a stability indicating HPLC with refractive detection method for determination of phosphate and phosphite and alendronate sodium in pharmaceutical dosage forms that can separate the drug from degradation products formed under the ICH suggested conditions (hydrolysis, oxidation, photolysis, and thermal stress).<smiles>NCCCC(O)(P(=O)(O)O)P(=O)(O)O</smiles>

Alendronate sodium trihydrate<smiles>O=P(O)(O)O</smiles>

Phosphate<smiles>O=[PH](O)O</smiles>

Phosphite
Figure 1. Structures of Alendonate sodium trihydrate, Phosphate and Phosphite.

\section{EXPERIMENTAL}

\section{Chemicals and reagents}

Samples of alendronate sodium tablets $70 \mathrm{mg}$ and alendronate sodium trihydrate standard (99.8\%) were supplied by Dr. Reddy's laboratories limited, Hyderabad, India. Phosphate and phosphite were procured from SigmaAldrich, Germany. The analytical grade formic acid and sodium hydroxide were purchased from Merck, Mumbai, India. High purity water was prepared by using Millipore Milli-Q Plus water purification system (Millipore, Milford, MA, USA).

Equipment

The chromatography analysis was performed using Waters Alliance 2695 separation module (Waters Corporation, Milford, USA) equipped with 2414 refractive index detector, degasser, quaternary pump and auto sampler system. The output signal was monitored and processed using Empower 2 software. Cintex digital water bath was used for hydrolysis studies. Photo-stability studies were carried out in photo-stability chamber (Sanyo, Leicestershire, UK). Thermal stability studies were performed in a dry air oven (Cintex, Mumbai, India). The $\mathrm{pH}$ of the solutions was measured by a pH meter (MettlerToledo, Switzerland). 


\section{Chromatographic Conditions}

The method was developed using Allsep anion $(150 \times 4.6 \mathrm{~mm}, 7 \mu \mathrm{m})$ column with mobile phase containing $5.3 \mathrm{mM}$ formic acid, $\mathrm{pH}$ adjusted to 3.5 with sodium hydroxide. The mobile phases were filtered through nylon $0.45 \mu \mathrm{m}$ membrane filters and degassed. The flow rate of the mobile phase was $1.2 \mathrm{~mL} / \mathrm{min}$. The column temperature was maintained at $35^{\circ} \mathrm{C}$ and the eluted compounds were monitored with refractive index detector by setting the detector cell temperature $30^{\circ} \mathrm{C}$ and sensitivity 64 . The injection volume was $100 \mu 1$ for related substances and dissolution sample analysis; and $20 \mu 1$ for assay sample analysis.

Preparation of system suitability Solution

Milli-Q water was used as diluent. A system suitability solution of alendronate sodium and phospahte with a concentration of $3.3 \mathrm{mg} / \mathrm{mL}$ and $10 \mu \mathrm{g} / \mathrm{mL}$, respectively, was prepared by dissolving appropriate amount of analytes in the diluent.

\section{Preparation of Standard Solutions}

For impurity determination, two stock solutions of phosphate and phosphite were prepared individually in diluent with a concentration of 25 $\mathrm{mg} / \mathrm{mL}$. Working standard solution was prepared from mixing above stock solutions of phosphite and phosphate with final concentration of $10 \mu \mathrm{g} / \mathrm{mL}$.

For the determination of amount of alendronte in tablet (assay), working standard solution of alendronate sodium was prepared by dissolving appropriate amount of drug in the diluent to get the concentration of $1.06 \mathrm{mg} / \mathrm{mL}$.

For the determination of \% release of alendronate in in-vitro dissolution sample, stock solution of alendronate sodium was prepared in diluent with a concentration of $1.26 \mathrm{mg} / \mathrm{mL}$. Working standard solution was prepared from above stock solution with final concentration of $100.8 \mu \mathrm{g} / \mathrm{mL}$.

\section{Preparation of sample Solutions}

For impurity determination, tablet powder equivalent to $83 \mathrm{mg}$ of alendronate was dissolved in diluents with sonication for $30 \mathrm{~min}$ to give a solution containing $3.3 \mathrm{mg} / \mathrm{mL}$ drug. This solution was centrifuged at 3000 $\mathrm{rpm}$ for $10 \mathrm{~min}$ and filtered through $0.45 \mu \mathrm{m}$ nylon filter.

For assay determination, five tablets (equivalent to $350 \mathrm{mg}$ alendronate) were dissolved in $500 \mathrm{~mL}$ diluent with sonication for $30 \mathrm{~min}$ to give a solution containing $0.7 \mathrm{mg} / \mathrm{mL}$ drug. This solution was centrifuged at $3000 \mathrm{rpm}$ for 10 $\mathrm{min}$ and filtered through $0.45 \mu \mathrm{m}$ nylon filter.

\section{Forced degradation study}

Forced degradation studies were performed to demonstrate selectivity and stability indicating capability of the proposed HPLC method. Stress studies were performed at $3.3 \mathrm{mg} / \mathrm{mL}$ concentration of alendronate on tablet to provide an indication of the stability-indicating property and specificity of proposed method. The stress condition employed for degradation study included acid hydrolysis $\left(0.2 \mathrm{~N} \mathrm{HCl}\right.$ at $75^{\circ} \mathrm{C}$ for $\left.24 \mathrm{hrs}\right)$, base hydrolysis $(0.2 \mathrm{~N} \mathrm{NaOH}$ at $75^{\circ} \mathrm{C}$ for $24 \mathrm{hrs}$ ), oxidation $\left(6 \% \mathrm{H}_{2} \mathrm{O}_{2}\right.$ at $75^{\circ} \mathrm{C}$ for $\left.20 \mathrm{hrs}\right)$, hydrolytic (water at $75^{\circ} \mathrm{C}$ for $24 \mathrm{hrs}$ ), thermal $\left(105^{\circ} \mathrm{C}\right.$ for $24 \mathrm{hrs}$ ) and photolytic degradation (drug product exposed to visible light for $240 \mathrm{hrs}$ resulting an overall illustration 1.2 million lux hours and UV light for $250 \mathrm{hrs}$ resulting an overall illustration 200 watt hours $/ \mathrm{m}^{2}$ at $25^{\circ} \mathrm{C}$ ).

\section{Dissolution test conditions}

Dissolution method reported in USP monograph of alendronate sodium tablets was used to perform the dissolution of alendronate sodium tablets [13]. A calibrated dissolution apparatus (USP apparatus II) was used with paddles at $75 \mathrm{rpm}$ and media temperature was maintained at $37 \pm 0.5^{\circ} \mathrm{C}$. Nine hundred milliliters of degassed purified water was used as dissolution medium. Two drug products $(6$ tablets per manufacturer) were evaluated and dissolution samples were collected at $15 \mathrm{~min}$. The $10 \mathrm{~mL}$ sample aliquots were removed from each vessel using an auto sampler. Samples were filtered through 0.45 $\mu \mathrm{m}$ nylon filters.

The amount of dissolved alendronate in the test samples was calculated as percent dissolution from the measured peak area response of alendronate $\left(r_{a}\right)$ for the test samples and compared to peak area response of alendronate $\left(r_{\mathrm{s}}\right)$ from the standard solution using the following equations:

$$
\text { Percentage of alendronate dissolved }=\frac{r_{\mathrm{d}}}{r_{\mathrm{s}}} \times(0.9 \times C) \times \frac{P}{L}
$$

Where, $C$ is the concentration in $\mu \mathrm{g} / \mathrm{mL}$ of the alendronate sodium working standard, $P$ is the potency of alendronate sodium working standard calculated as alendronate in $\% \mathrm{w} / \mathrm{w}, L$ is the claimed amount of alendronate, in $\mathrm{mg}$ per tablet.

\section{RESULTS AND DISCUSSION}

\section{Method Development and Optimization}

The main objective of this work was to develop a stability indicating HPLC-RI method for the determination of phosphate, phosphite and alendronate in pharmaceutical formulation without derivatization. Alendronate sodium is a highly polar compound and don't have UV response due to lack of chromophore groups. The target of chromatographic method was to retain alendronate and separate critical closely eluting phosphate and phosphite. A blend containing $3.3 \mathrm{mg} / \mathrm{mL}$ of alendronate sodium and $10 \mu \mathrm{g} / \mathrm{mL}$ of each phosphate and phosphite were used for separation. An isocratic method employed using $0.01 \mathrm{M}$ potassium dihydrogen orthophosphate $(\mathrm{pH} 3.0)$ and methanol in the ratio of 95:5 as mobile phase, Hypersil BDS C18 (250 mm X $4.6 \mathrm{~mm}) 5 \mu \mathrm{m}$ column with flow rate of $1.0 \mathrm{~mL} / \mathrm{min}$ on HPLC equipped with refractive index detector. All three compounds were not retained and eluted in the void. To retain and separate the phosphate, phosphite and alendronate, an attempt was made by using Allsep anion, $150 \mathrm{~mm}$ x $4.6 \mathrm{~mm}, 7 \mu \mathrm{m}$ column with mobile phase containing $5.3 \mathrm{mM}$ formic acid buffer, adjusted $\mathrm{pH}$ to 3.0 with sodium hydroxide solution. All three compounds were retained but phosphite eluted too late. To reduce the run time, $\mathrm{pH}$ of mobile phase was increased to 3.5 and all peaks were found well separated in 30 min run time with a resolution greater than 2.0. Detector parameters were optimized to get enough sensitivity and minimum noise. Based on these experiments, the conditions were further optimized as described under chromatographic conditions section.

\section{Method Validation}

The proposed method was validated as per ICH guidelines ${ }^{15-17}$. The following validation characteristics were addressed: specificity, accuracy, precision, limit of detection and quantification, linearity, range and robustness.

\section{System suitability}

System suitability was determined before sample analysis from six replicate injections of the standard solution containing $10 \mu \mathrm{g} / \mathrm{mL}$ of each phosphite and phosphate for related substances. The acceptance criteria were less than $5 \%$ relative standard deviation (RSD) for peak areas, USP tailing factor less than 2.0 for phosphate and phosphite peaks from standard solution; and resolution between alendronate and phosphate peak not less than 2.0 from system suitability solution.

For assay and dissolution test, system suitability was evaluated from five replicate injections of the alendronate sodium standard solution. The acceptance criteria were less than $2 \%$ relative standard deviation (RSD) for peak areas and USP tailing factor less than 2.0 for alendronate peak.

\section{Specificity/Stress studies}

Specificity is the ability of the method to measure the analyte response in the presence of its potential impurities and placebo components. Forced degradation studies were performed to demonstrate selectivity and stability indicating capability of the proposed HPLC method. Figure 2 shows that there is no any interference at the retention time of alendronate, phosphate and phosphite due to blank and placebo. Alendronate sodium tablets were subjected to the stress conditions of oxidative, acid, base, hydrolytic, thermal and photolytic degradation. Degradation was not observed when alendronate was subjected to acid, base, thermal, hydrolytic and photostability conditions. Significant degradation was observed when the drug product was subjected to oxidative hydrolysis $\left(6 \% \mathrm{H}_{2} \mathrm{O}_{2}\right.$ at $75^{\circ} \mathrm{C}$ for $\left.20 \mathrm{hrs}\right)$ leading to the formation of phosphate. Chromatogram of peroxide degradation study is presented in Figure 3. Results from force degradation studies are shown in Table-1.

The mass balance for the stressed samples was close to $97.5 \%$. Assay of alendronate was unaffected by the presence of degradation products, confirming the stability-indicating power of the method.

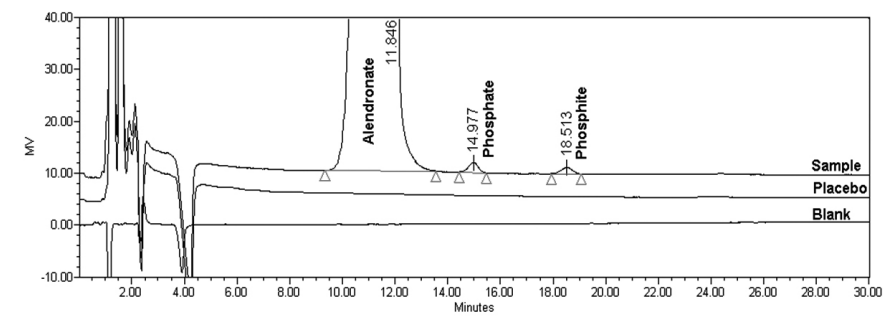

Figure 2: Overlay chromatograms of blank, placebo and sample of related substances analysis. 


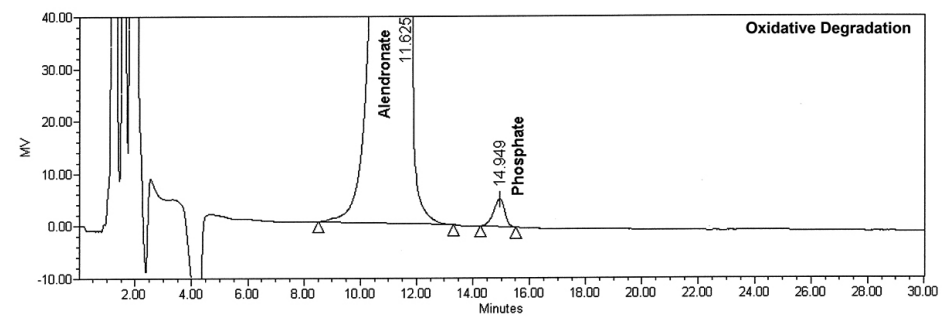

Figure 3: Typical chromatogram of oxidative degradation sample

Table 1: Summary of forced degradation results.

\begin{tabular}{|c|c|c|c|c|c|}
\hline \multirow{2}{*}{ Stress Condition } & \multicolumn{2}{|c|}{$\%$ Impurity } & \multirow{2}{*}{$\begin{array}{c}\% \text { Net } \\
\text { Degrad-ation }\end{array}$} & \multirow{2}{*}{$\begin{array}{c}\% \text { Assay of } \\
\text { active substance }\end{array}$} & \multirow{2}{*}{$\begin{array}{l}\text { Mass balance } \\
\quad(\%)\end{array}$} \\
\hline & Phosphate & Phosphite & & & \\
\hline $\begin{array}{c}\text { Acid hydrolysis } \\
\left(0.2 \mathrm{~N} \mathrm{HCl} \text { at } 75^{\circ} \mathrm{C}, 24 \mathrm{hrs}\right)\end{array}$ & ND & ND & Nil & 97.7 & 97.7 \\
\hline $\begin{array}{c}\text { Base hydrolysis } \\
\left(0.2 \mathrm{~N} \mathrm{NaOH} \text { at } 75^{\circ} \mathrm{C}, 24 \mathrm{hrs}\right)\end{array}$ & ND & ND & Nil & 99.6 & 99.6 \\
\hline $\begin{array}{c}\text { Oxidation } \\
\left(6 \% \mathrm{H}_{2} \mathrm{O}_{2} \text { at } 75^{\circ} \mathrm{C}, 24 \mathrm{hrs}\right)\end{array}$ & 1.5 & ND & Nil & 96.3 & 97.8 \\
\hline $\begin{array}{c}\text { Thermal } \\
\text { (At } 105^{\circ} \mathrm{C}, 24 \mathrm{hrs} \text { ) }\end{array}$ & ND & ND & Nil & 98.3 & 98.3 \\
\hline $\begin{array}{c}\text { Hydrolytic } \\
\text { (Water at } 75^{\circ} \mathrm{C}, 24 \mathrm{hrs} \text { ) }\end{array}$ & ND & ND & Nil & 97.5 & 97.5 \\
\hline $\begin{array}{l}\text { Photolytic (1.2 million lux hrs visible } \\
\text { light and } 200 \mathrm{wh} / \mathrm{m}^{2} \mathrm{UV} \text { light) }\end{array}$ & ND & ND & Nil & 98.9 & 98.9 \\
\hline
\end{tabular}

$\mathrm{ND}=$ Not detected

Nil $=$ No degradation observed.

\section{Precision}

The precision of method was verified by repeatability and intermediate precision. Repeatability was checked by injecting six individual preparations of alendronate sodium tablets spiked with phosphate and phosphite at $0.30 \%$ level ( $0.30 \%$ of impurities with respect to $3.3 \mathrm{mg} / \mathrm{mL}$ alendronate). The intermediate precision of the method was also evaluated using different analyst and different instrument and performing the analysis on different days. The RSD (\%) of peak areas was calculated for phosphate and phosphite. The precision of the assay and dissolution was evaluated by performing six independent analysis of test samples of alendronate and comparison with reference standard. The RSD (\%) of six results was calculated. Results are presented in Table 2 along with intermediate precision data. Low values of $\%$ RSD, indicates that the method is precise.

Limits of Detection (LOD) and Quantification (LOQ)

The LOD and LOQ for phosphate and phosphite were determined at a signal-to-noise ratio of 3:1 and 10:1, respectively, by injecting a series of dilute solutions with known concentrations. LOD values for phosphate and phosphite were found to be 0.666 and $1.094 \mu \mathrm{g} / \mathrm{mL}$, respective; and LOQ values for phosphate and phosphite were found to be 1.997 and $2.885 \mu \mathrm{g} / \mathrm{mL}$, respective.
Precision study was also carried out at the LOQ level by injecting six individual preparations of phosphate and phosphite. The \%RSD of the areas of phosphate and phosphite were found to be 2.8 and 2.4 , respectively.

\section{Linearity}

Linearity test solutions were prepared by diluting the stock solutions to the required concentrations. The solutions were prepared at six concentration levels from LOQ to $300 \%$ of specification level (LOQ, $0.25 \% .0 .38 \%, 0.50 \%$, $0.75 \%$ and $1.0 \%$ for phosphate and phosphite). For assay method, linearity method was demonstrated from $50 \%$ to $200 \%$ of standard concentration using five calibration levels $(50 \%, 75 \%, 100 \%, 150 \%$ and $200 \%)$ for alendronate compound and linearity for dissolution method was performed from $10 \%$ to $150 \%$ of standard concentration using six calibration levels $(10 \%, 50 \%, 75 \%$, $100 \%, 150 \%$ and $200 \%$ ) for alendronate. Calibration curves were plotted between the responses of peak versus analyte concentrations. The coefficient correlation, slope and y-intercept of the calibration curve are reported (Table-2). The correlation coefficient obtained was greater than 0.999. The above result shows that an excellent correlation existed between peak area and concentration of alendronate, phosphate and phosphite.

Table 2: Results from linearity and precision study.

\begin{tabular}{|c|c|c|c|c|}
\hline Parameter & Phosphate & Phosphite & Alendronate $^{\text {a }}$ & Alendronate $^{\text {b }}$ \\
\hline Correlation coefficient & 0.999 & 0.998 & 0.999 & 0.999 \\
\hline Intercept (a) & -15924.91 & -1015.796 & -15924.91 & -10727.19 \\
\hline Slope (b) & 1964.49 & 57697.960 & 1964.49 & 7562.81 \\
\hline Bias at 100\% response & 1.8 & -1.1 & 1.8 & -1.9 \\
\hline Precision (\%RSD) & 0.8 & 0.9 & 0.8 & 1.7 \\
\hline Intermediate precision (\%RSD) & 0.7 & 0.9 & 1.6 & 1.8 \\
\hline
\end{tabular}

${ }^{a}$ Linearity of assay method

${ }^{\mathrm{b}}$ Linearity of dissolution method 


\section{Accuracy}

Accuracy of the method for phosphate and phosphite was evaluated in triplicate using six concentration levels LOQ, $50 \%, 75 \%, 100 \%, 150 \%$ and $200 \%$ of target concentration level, i.e. $0.30 \%$ of alendronate analyte concentration $(3.3 \mathrm{mg} / \mathrm{mL})$. To confirm the accuracy of assay and dissolution method, recovery studies were carried out by standard addition technique. Five different levels $(50 \%, 75 \%, 100 \%, 125 \%$ and $150 \%)$ of standards were added to pre-analyzed placebo samples in triplicate. The mean of percentage recoveries and the \% RSD was calculated. The result of recoveries for alendronate, phosphate and phosphite are shown in Table 3.

Table 3: Evaluation of recovery data.

\begin{tabular}{|c|c|c|c|c|}
\hline \multirow{2}{*}{ Amount spiked } & \multicolumn{4}{|c|}{ \% Recovery $^{\mathrm{a}}$} \\
\cline { 2 - 5 } & Phosphate & Phosphite & Alendronate $^{\mathrm{b}}$ & Alendronate $^{\mathrm{c}}$ \\
\hline LOQ & $100.9 \pm 4.2$ & $94.0 \pm 2.6$ & NA & NA \\
\hline $50 \%$ & $100.0 \pm 1.2$ & $100.9 \pm 0.6$ & $97.5 \pm 0.7$ & $111.6 \pm 0.9$ \\
\hline $75 \%$ & $100.0 \pm 1.3$ & $100.8 \pm 1.8$ & $98.9 \pm 0.2$ & $108.2 \pm 3.3$ \\
\hline $100 \%$ & $103.3 \pm 1.2$ & $101.4 \pm 1.5$ & $100.8 \pm 0.2$ & $103.1 \pm 4.5$ \\
\hline $125 \%$ & $99.8 \pm 0.7$ & $102.3 \pm 1.4$ & $100.0 \pm 0.2$ & $102.5 \pm 1.9$ \\
\hline $150 \%$ & $101.2 \pm 0.9$ & $103.3 \pm 1.3$ & $101.5 \pm 0.2$ & $100.0 \pm 1.0$ \\
\hline
\end{tabular}

${ }^{a}$ Mean $+\%$ RSD for three determinations

${ }^{\mathrm{b}}$ Recovery of alendronate from assay sample.

${ }^{\mathrm{c}}$ Recovery of alendronate from dissolution sample.

NA $=$ Not applicable

\section{Robustness}

To determine the robustness of the developed method, experimental conditions were deliberately altered and the resolution between alendronate and phosphate; and system suitability parameters for alendronate standard were recorded. The variables evaluated in the study were $\mathrm{pH}$ of the mobile phase buffer $( \pm 0.2)$, column temperature $\left( \pm 5^{\circ} \mathrm{C}\right)$ and flow rate $( \pm 0.2 \mathrm{~mL} / \mathrm{min})$ of mobile phase. No significant effect was observed on system suitability parameters such as resolution, tailing factor and $\%$ RSD of alendronate, when small but deliberate changes were made to chromatographic conditions. The results are reported in Table 4 . Thus, the method was found to be robust with respect to variability in above conditions.

Table 4: Robustness results of HPLC method.

\begin{tabular}{|c|c|c|c|c|c|}
\hline \multirow[b]{2}{*}{$\begin{array}{l}\text { Variation in } \\
\text { chromatographic condition }\end{array}$} & \multicolumn{5}{|c|}{ Observed system suitability parameters } \\
\hline & $\begin{array}{c}\text { USP Resolution }^{\mathrm{a}} \\
\quad \geq 2.0\end{array}$ & $\begin{array}{c}\text { USP Tailing for } \\
\text { Phosphate peak } \\
\leq 2.0\end{array}$ & $\begin{array}{c}\text { USP Tailing for } \\
\text { Phosphite peak } \\
\leq 2.0\end{array}$ & $\begin{array}{c}\% \text { RSD of } \\
\text { Phosphate peak } \\
\text { area } \\
\leq 5.0(\mathrm{n}=6)\end{array}$ & $\begin{array}{c}\% \text { RSD of } \\
\text { Phosphite peak } \\
\text { area } \\
\leq 5.0(\mathrm{n}=6)\end{array}$ \\
\hline Column Temperature $30^{\circ} \mathrm{C}$ & 2.0 & 1.1 & 1.1 & 0.6 & 1.1 \\
\hline Column Temperature $40^{\circ} \mathrm{C}$ & 2.0 & 1.0 & 1.0 & 1.5 & 1.3 \\
\hline Flow rate $1.0 \mathrm{~mL} / \mathrm{min}$ & 2.1 & 1.1 & 1.1 & 1.1 & 1.0 \\
\hline Flow rate $1.4 \mathrm{~mL} / \mathrm{min}$ & 2.4 & 1.0 & 1.0 & 0.6 & 1.5 \\
\hline Mobile Phase Buffer pH 3.4 & 4.2 & 1.2 & 1.1 & 2.3 & 2.2 \\
\hline Mobile Phase Buffer pH 3.6 & 2.1 & 1.1 & 1.1 & 1.7 & 1.2 \\
\hline
\end{tabular}

${ }^{\text {a }}$ Resolution between alendronate and phosphate.

\section{Standard and sample Solution Stability}

Stability of sample and standard solution was established by storage of sample solution at ambient temperature for $48 \mathrm{hrs}$. Alendronate sample solution was re-analyzed after 24 and $48 \mathrm{hrs}$ time intervals. The solution stability of alendronate, phosphate and phosphite was determined by leaving test solution and standard solutions in tightly capped volumetric flasks at room temperature for $48 \mathrm{hrs}$ and measured the amount of alendronate, phosphate and phosphite at every $24 \mathrm{hrs}$ against freshly prepared standard solution. No significant changes were observed in the content of alendronate, phosphate and phosphite during solution stability and experimental data confirms that the standard and sample solutions were stable for $48 \mathrm{hrs}$.

Analysis of Alendronate sodium tablets

Samples of alendronated tablets were analyzed to estimate the amount of alendronate (assay) and related substances (phosphate and phosphite). The \% assay of alendronate in the tablet was $99.7 \%$ and; phosphate and phosphite impurities were not detected in the sample.

\section{In-vitro dissolution studies}

The dissolution characteristics of alendronate sodium are given in figure-5. Analyzing the in vitro dissolution profiles of product $\mathrm{A}$ and $\mathrm{B}$, it could be concluded that product $\mathrm{B}$ showed the little faster release rate than that of product A. Initially at $5 \mathrm{~min}$, dissolution rate of product B is slightly faster than product $\mathrm{A}$, but from $10 \mathrm{~min}$ to $20 \mathrm{~min}$ both product $\mathrm{A}$ and $\mathrm{B}$ were released completely (more than 90\%) and meet the acceptance criteria mentioned in USP monograph. Based on these observations from product A and B, it could be concluded that the dissolution method mentioned above would be appropriate to simulate the in vitro release of alendronate sodium for product $\mathrm{A}$ and $\mathrm{B}$. 


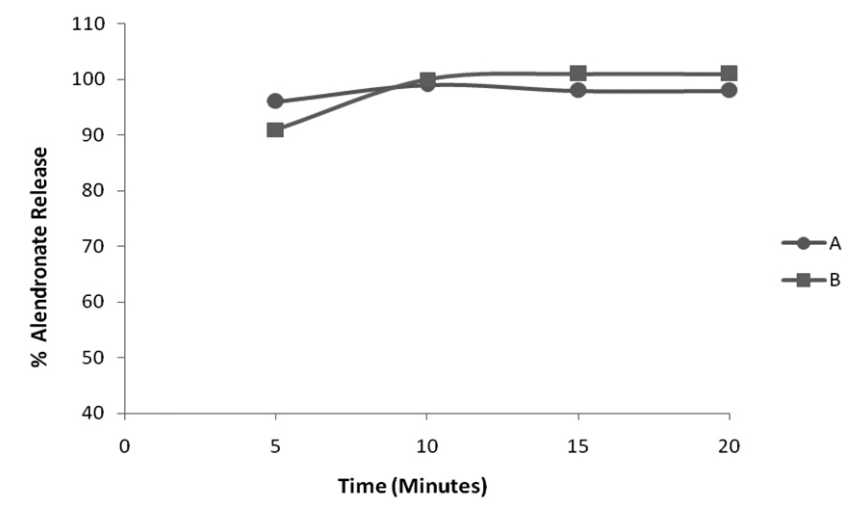
and $\mathrm{B}$.

Figure 5: Dissolution profiles of Alendronate sodium tablets products A

\section{CONCLUSIONS}

We have developed a simple, economic and stability indicating HPLCRI method for the quantitative determination of phosphate, phosphite and alendronate in pharmaceutical formulation without derivatization. Developed method was validated in accordance with $\mathrm{ICH}$ guidelines with respect to specificity, precision, accuracy linearity, limit of detection, limit of quantification and robustness. Satisfactory results were obtained from the validation of the method. Developed method was also applied for the study of in vitro dissolution profiles in pharmaceutical dosage forms. The method is stability indicating and can be used for routine analysis of production samples and to check the stability of the alendronate sodium tablets.

\section{ACKNOWLEDGEMENT}

The authors are thankful to the management of Dr. Reddy's Laboratories Ltd., Hyderabad for providing facilities to carry out this work.

\section{REFERENCES}

1. http://www.rxlist.com/fosamax-drug.htm

2. H.P. Sleeboom, O. L. M. Bijvoet, A. T. Van Oosterom, J. H. Gleed and J. L. H.O'Riordan, Lancet, 2, 239, (1983).

3. W. F. Kline, B. K. Matuszewski, J. Chromatogr. B, 583, 183, (1992).

4. M. J. Lovhahl, D. J. Pietrzyk, J. Chromatogr. A, 850, 143, (1999).

5. E. W. Tsai, D. P. Ip, M. A. Brooks, J. Chromatogr. A, 596, 217, (1992).

6. C. Fernandes, R. S. Leite, F. M. Lancas, J. Chromatogr. Sci., 45, 236, (2007).

7. M. H. Yun, J. S. Woo, K. Kwon, Arch. Pharm. Res., 29 (4), 328, (2006).

8. M. H. Yun, K. Kwon, J. Pharm. Biomed. Anal., 40, 168, (2006).

9. H. S. Kang, S. J. Hwang, J. S. Park, C. K. Kim, J. Liq. Chromatogr. Rel. Technol., 29, 1589, (2006).

10. X. Z. Qin, E. W. Tsai, T. Sakuma, D. P. Ip, J. Chromatogr. A, 686, 205, (1994).

11. P. Ptacek, J. Klima, J. Macek, J. Chromatogr. B, 767, 111, (2002).

12. J. D. De Marco, S. E. Biffar, D. G. Reed, M. A. Brook, J. Pharm. Biomed. Anal., 7 1719, (1989).

13. The United States Pharmacopoeia, $34^{\text {th }}$ edn, 2011, The convention, 12601 Rockville, pp. 1783.

14. Y. H. R. Han, X. Z. Qin, J. Chromatogr. A, 719, 345, (1996).

15. ICH Q2 (R1), Validation of Analytical Procedures: Text and Methodology, International Conference on Harmonization, 2005.

16. ICH Q1A (R2), Stability Testing of new Drug Substances and Products, International Conference on Harmonization, 2003.

17. ICH Q1B, Stability Testing: Photo stability testing of new Drug Substances and Products, International Conference on Harmonization, 1997. 